Prepared in cooperation with the U.S. Fish and Wildlife Service and Bureau of Reclamation

Effects of Microcystin-LR on Juvenile Lost River Suckers (Deltistes luxatus) during Feeding Trials, Upper Klamath Lake, Oregon, 2014-16

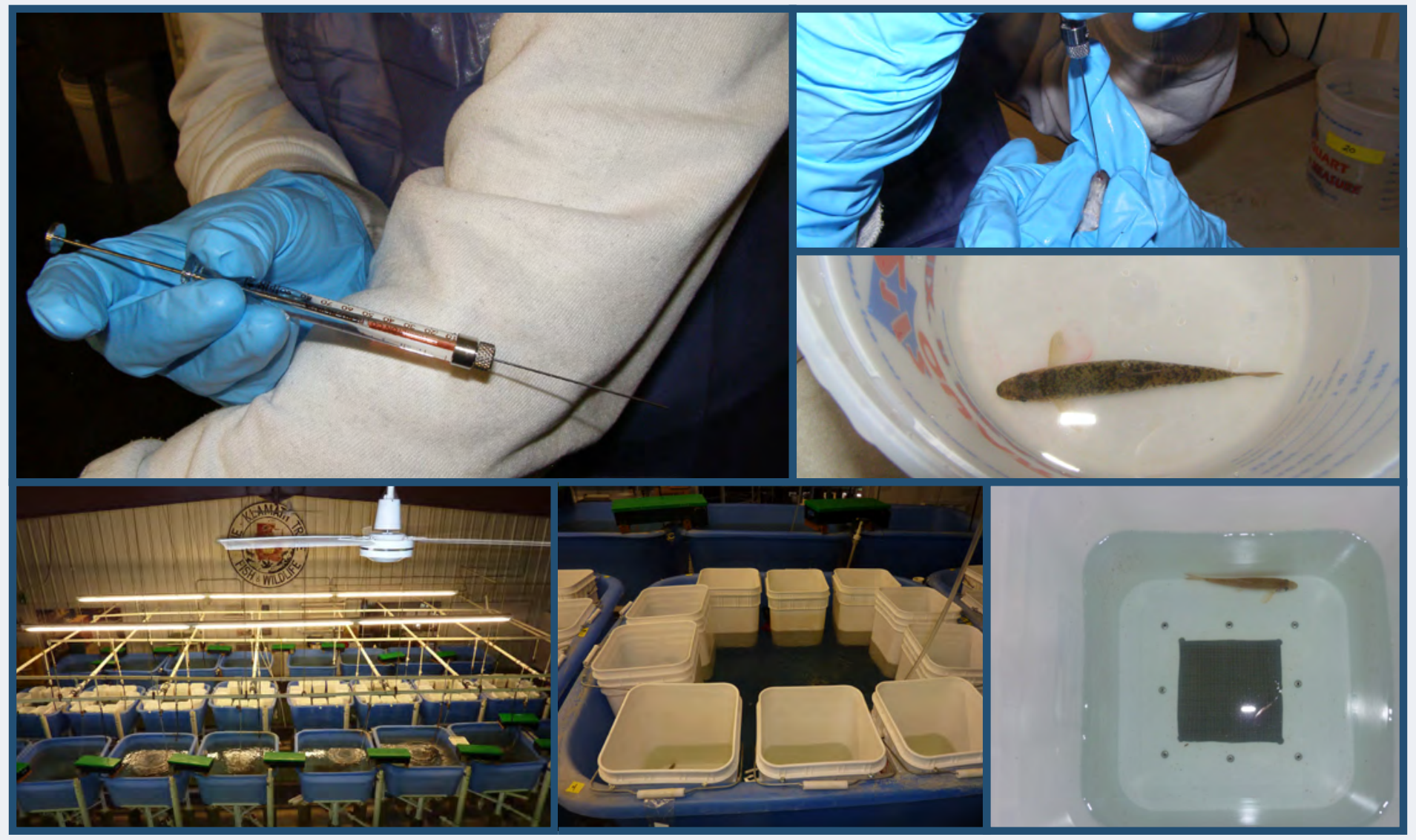

Open-File Report 2019-1079 
Cover: Front cover photographs, from left to right: (1) Colored water containing microcystin dose (taken by Kris Fischer, Klamath Tribes, January 2014); (2) Gavage of microcystin into fish (taken by Kris Fischer, Klamath Tribes, January 2014); (3)

Expulsion of microcystin through the gills as seen by red dye next to the fish (taken by Kris Fischer, Klamath Tribes, January 2014); (4) Overview of experimental setup with 10 buckets hanging in each blue fish tank (taken by Barbara Martin, U.S. Geological Survey, April 2014); (5) Close-up of buckets hanging in the fish tank (taken by Barbara Martin, USGS, April 2014); (6) Close-up looking at juvenile Lost River Sucker in bucket (taken by Barbara Martin, USGS, April 2014). 


\section{Effects of Microcystin-LR on Juvenile Lost River Suckers (Deltistes luxatus) during Feeding Trials, Upper Klamath Lake, Oregon, 2014-16}

By Barbara A. Martin, Kathy R. Echols, Diane G. Elliott, Kevin Feltz, Carla M. Conway, and Summer M. Burdick

Prepared in cooperation with the U.S. Fish and Wildlife Service and Bureau of Reclamation

Open-File Report 2019-1079

U.S. Department of the Interior U.S. Geological Survey 



\section{U.S. Department of the Interior \\ DAVID L. BERNHARDT, Secretary}

\section{U.S. Geological Survey James Reilly, Director}

U.S. Geological Survey, Reston, Virginia: 2019

For more information on the USGS-the Federal source for science about the Earth, its natural and living resources, natural hazards, and the environment-visit http://www.usgs.gov/ or call 1-888-ASK-USGS (1-888-275-8747).

For an overview of USGS information products, including maps, imagery, and publications, visit https://store.usgs.gov/.

Any use of trade, firm, or product names is for descriptive purposes only and does not imply endorsement by the U.S. Government.

Although this information product, for the most part, is in the public domain, it also may contain copyrighted materials as noted in the text. Permission to reproduce copyrighted items must be secured from the copyright owner.

Suggested citation:

Martin, B.A., Echols, K.R., Elliott, D.G., Feltz, K., Conway, C.M., and Burdick, S.M., 2019, Effects of microcystin-LR on juvenile Lost River suckers (Deltistes luxatus) during feeding trials, Upper Klamath Lake, Oregon, 2014-16: U.S. Geological Survey Open-File Report 2019-1079, 22 p., https://doi.org/10.3133/ofr20191079.

ISSN 2331-1258 (online) 


\section{Contents}

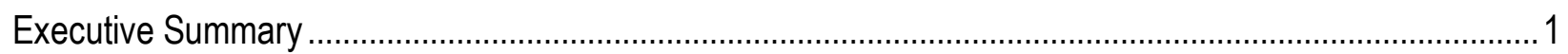

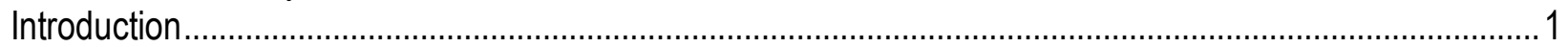

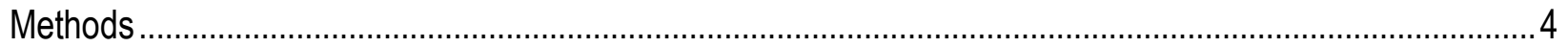

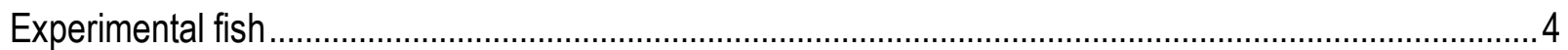

Evaluation of Toxin Delivery Methods.............................................................................................

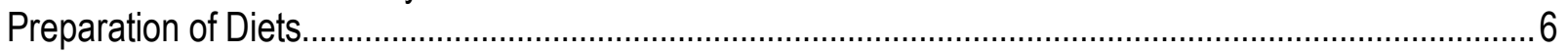

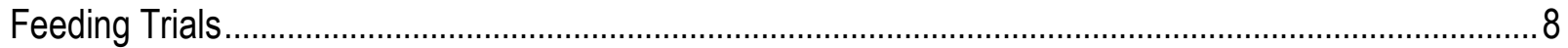

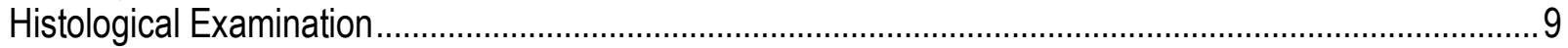

Microcystin Tissue Analysis ....................................................................................................

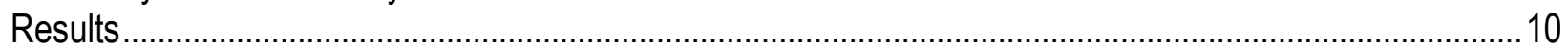

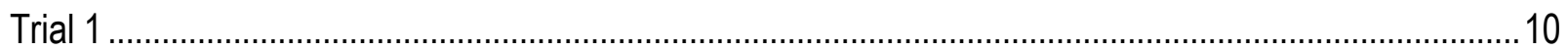

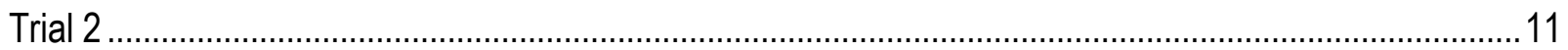

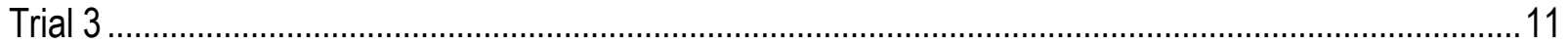

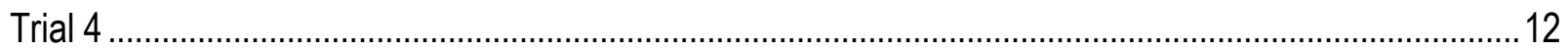

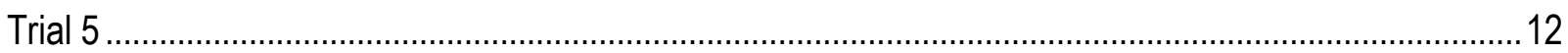

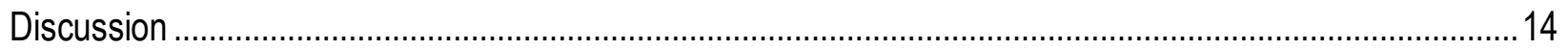

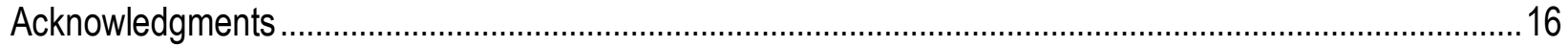

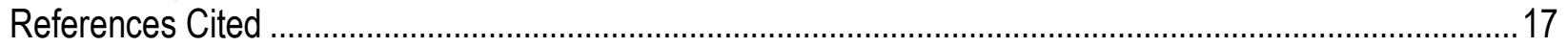

\section{Figures}

Figure 1. Image showing immunohistochemical staining of posterior intestinal epithelial tissue and digestive contents for MC-LR in a fish that received a daily 60 microgram dose for 14 days in Trial 5 ........13

\section{Tables}

Table 1. List of microcystin trials performed and vital statistics on the fish used for those trials....................5

Table 2. Amount of MC-LR that leached from pelleted S-2 food soaked in deionized water for 24 hours. ....6

Table 3. Microcystin dose per fish used in single dose trials and resulting estimated body burden ...............

Table 4. Microcystin daily dose per fish in chronic feeding trials and resulting estimated daily and total body

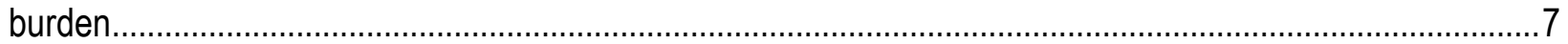

Table 5. Numbers of Lost River suckers showing positive results for the presence of microcystin antigen by immunohistochemical testing.

Table 6. Average amount of MC-LR recovered in whole fish following single dose feeding trials, shown by dose and holding time after ingestion.

Table 7. Average amount of MC-LR recovered in fish during chronic trials 24 hours after ingestion of the last meal. 


\section{Conversion Factors}

International System of units to U.S. customary units

\begin{tabular}{|c|c|c|}
\hline Multiply & By & To obtain \\
\hline \multicolumn{3}{|c|}{ Length } \\
\hline millimeter $(\mathrm{mm})$ & 0.03937 & inch (in.) \\
\hline micrometer $(\mu \mathrm{m})$ & $3.9370 \times 10^{-5}$ & inch (in.) \\
\hline nanometer (nm) & $3.2808 \times 10^{-8}$ & inch (in.) \\
\hline \multicolumn{3}{|c|}{ Volume } \\
\hline liter $(\mathrm{L})$ & 33.814 & ounce, fluid (fl. oz) \\
\hline milliliter $(\mathrm{mL})$ & 0.03381 & ounce, fluid (fl. oz) \\
\hline microliter $(\mu \mathrm{L})$ & $3.3814 \times 10^{-4}$ & ounce, fluid (fl. oz) \\
\hline \multicolumn{3}{|c|}{ Mass } \\
\hline kilogram (kg) & 35.274 & ounce, avoirdupois (oz) \\
\hline $\operatorname{gram}(\mathrm{g})$ & 0.03527 & ounce, avoirdupois (oz) \\
\hline milligram (mg) & $3.5274 \times 10^{-5}$ & ounce, avoirdupois (oz) \\
\hline microgram $(\mu \mathrm{g})$ & $3.5274 \times 10^{-8}$ & ounce, avoirdupois (oz) \\
\hline nanogram (ng) & $3.5274 \times 10^{-11}$ & ounce, avoirdupois (oz) \\
\hline
\end{tabular}

Temperature in degrees Celsius $\left({ }^{\circ} \mathrm{C}\right)$ may be converted to degrees Fahrenheit $\left({ }^{\circ} \mathrm{F}\right)$ as follows:

$$
{ }^{\circ} \mathrm{F}=\left(1.8 \times{ }^{\circ} \mathrm{C}\right)+32
$$

Concentrations of chemical constituents in water are given either in milligrams per liter $(\mathrm{mg} / \mathrm{L})$ or in micrograms per liter $(\mu \mathrm{g} / \mathrm{L})$. 


\section{Abbreviations and Acronyms}

\begin{tabular}{ll}
\hline $\begin{array}{l}\text { Abbreviation } \\
\text { or acronym }\end{array}$ & \multicolumn{1}{c}{ Meaning } \\
\hline bm & Body mass \\
df & Degrees of freedom \\
DI & Deionized \\
DNA & Deoxyribonucleic acid \\
ELISA & Enzyme-linked immunosorbent assay \\
h & hour \\
HPLC & High-performance liquid chromatography \\
IP & Intraperitoneal \\
LA & leucine alanine \\
LR & leucine arginine \\
MC & Microcystin \\
RR & arginine arginine \\
RNA & Ribonucleic acid \\
SL & Standard length \\
UV & Ultraviolet \\
$X^{2}$ & Chi squared value \\
YR & tyrosine arginine \\
\hline
\end{tabular}




\section{Effects of Microcystin-LR on Juvenile Lost River Suckers (Deltistes luxatus) during Feeding Trials, Upper Klamath Lake, Oregon, 2014-16}

By Barbara A. Martin, Kathy R. Echols, Diane G. Elliott, Kevin Feltz, Carla M. Conway, and Summer M. Burdick

\section{Executive Summary}

Historically, populations of Lost River suckers (Deltistes luxatus) of the Upper Klamath Basin were so numerous that they were commercially harvested; however, declining numbers throughout the 20th century led to the listing of the species under the United States Endangered Species Act in 1988. Habitat destruction, poor water quality, competition with (and predation by) nonnative species, especially fathead minnows (Pimephales promelas) and yellow perch (Perca flavescens), are hypothesized as primary causes of population decline (U.S. Fish and Wildlife Service, 2013). Age data indicate that almost all adult suckers presently in Upper Klamath Lake spawning populations were hatched in the early 1990s. While entrainment of young fish (especially larvae) may contribute, catch-at-length and age data suggest consistently high mortality during the first year of life may be preventing the recruitment of young adults. The specific causes of juvenile sucker mortality are unknown; however, the absence of juvenile suckers in trap net catches coincides with degraded water quality associated with the decay of cyanobacteria blooms and exposure to toxic microcystin produced by Microcystis cyanobacteria.

Water-quality data collected in Upper Klamath Lake from 2011 to 2016 suggest that microcystin concentrations in Upper Klamath Lake reached potentially lethal levels based on literature findings from studies on a variety of fish species. We conducted a laboratory feeding trial to determine if microcystin toxicity could potentially be a direct cause of juvenile Lost River sucker mortality. We examined the effects of environmentally relevant doses of microcystin on the survival and health of hatchery-reared juvenile Lost River suckers. Results from this laboratory study suggest that Lost River suckers are very tolerant of the microcystin-LR toxin. Histopathological analysis revealed no evidence of tissue changes associated with microcystinLR exposure. Although no direct effects of microcystin-LR exposure were detected, suckers could potentially be negatively affected through added energy expenditures and stress associated with excretion of microcystin. Furthermore, microcystin may adversely affect other organisms in Upper Klamath Lake that could alter food availability or habitat of the suckers.

\section{Introduction}

The primary threat to the persistence of endangered Lost River suckers (Deltistes luxatus) in Upper Klamath Lake, Oregon, is a prolonged lack of recruitment into spawning populations (Hewitt and others, 2015). In Upper Klamath Lake, capture-recapture modeling and population age structure data indicate that the majority of spawners were hatched in the early 1990s (Hewitt and others, 2015). Although suckers are long-lived fish and therefore have adapted their life 
histories for extended periods of poor recruitment, they cannot survive decades of little to no recruitment into the spawning population. Comprehensive sampling of juvenile suckers indicates that this life stage consistently suffers unsustainably high mortality during the first 2 years of life, with the majority of fish not surviving to age 1 and the death of virtually all of the juveniles before they reach age 2 (Burdick and Martin, 2017). The phenomenon appears to occur at a large scale (the entire lake), with juvenile suckers no longer captured in trap nets throughout the lake over a relatively short time period during late summer and early fall (Burdick and Martin, 2017). Suckers in Clear Lake Reservoir have multiple year classes that have been captured with the same gear type, indicating that the lack of juveniles in trap nets in Upper Klamath Lake is not normal. Many hypotheses about the disappearance of juvenile suckers in Upper Klamath Lake have been investigated including factors related to parasites, disease, predation, habitat loss, emigration, and water quality (U.S. Fish and Wildlife Service, 2012). However, the presently available evidence doesn't rule out or strongly support any of these as primary factors causing the rapid disappearance of juvenile suckers. The disappearance of juvenile suckers from trap net catches roughly coincides with episodic decay of massive blooms of cyanobacteria, widespread hypoxia, and high concentrations of cyanotoxins, suggesting an association between high mortality and degraded water quality. In this report, we investigate the potential harmful effects to juvenile Lost River suckers of the hepatotoxin microcystin leucine arginine (MC-LR), a specific component of degraded water quality.

Blooms of the hepatotoxin-producing Microcystis aeruginosa occur in Upper Klamath Lake annually following the decline of massive annual blooms of Aphanizomenon flos-aquae. A. flos-aquae blooms undergo periods of rapid cell death once or twice each summer, leading to increased bioavailable nitrogen and phosphorus that in turn promote a bloom of the nonnitrogen-fixing cyanobacterium $M$. aeruginosa (Eldridge and others, 2012). Under certain circumstances, M. aeruginosa can produce hepatotoxic microcystins (Driscoll and others, 2018). While shoreline surface accumulations of $M$. aeruginosa can produce microcystin concentrations as high as $30 \mathrm{mg} / \mathrm{L}$, offshore cell-bound concentrations are less than or equal to 951 micrograms per liter $(\mu \mathrm{g} / \mathrm{L})$ (Jacoby and Kann, 2007; Caldwell Eldridge and others, 2013). Newly deposited sediment concentrations (typically less than or equal to 38.2 micrograms per gram $[\mu \mathrm{g} / \mathrm{g}]$ ) are usually less than cell-bound water concentrations, but sediment concentrations as high as 1,107 $\mu \mathrm{g} / \mathrm{g}$ have been recorded in a single mid-summer sample (Caldwell Eldridge and others, 2013). Dissolved microcystin concentrations in Upper Klamath Lake are much lower (less than or equal to $3.93 \mu \mathrm{g} / \mathrm{L}$; Caldwell Eldridge and others, 2013). Of the over 250 known variants of microcystin with different toxin potency, three (Microcystin tyrosine arginine [MC-YR], MCLR, and Microcystin leucine alanine [MC-LA]) are known to be produced in Upper Klamath Lake (Roy-Lachapelle and others, 2017). Of these the LR and LA variants are more toxic, at least when injected into mice (Zurawell and others, 2005). In 2012, the Klamath Tribes tested Upper Klamath Lake water from July through September for microcystin variants and determined that the major variant was LR (69 percent) followed by YR (31 percent); the additional variants (arginine arginine [RR], LA) were not detectable during this pilot study (Kris Fischer, personal communication).

Although some fishes appear to be exposed to microcystins through the gills (Cazenave and others, 2005), it appears more common that fish are exposed to microcystin through their diet (Zurawell and others, 2005; Ibelings and Havens, 2008). Dissolved microcystin concentrations in Upper Klamath Lake are below known lethal levels for fish and were not the focus of this study (Liu and others, 2014). The dietary exposure route of microcystins was 
confirmed for suckers in the digestive contents of 45 suckers that had ingested chironomid larvae that had themselves ingested whole M. aeruginosa cells (VanderKooi and others, 2010). Juvenile Lost River suckers are primarily benthic feeders (Markle and Clauson, 2006). Therefore, we consider the newly deposited whole-cell microcystin concentrations the most relevant source of information about potential exposure levels (Caldwell Eldridge and others, 2013).

When microcystins are ingested by fishes, the damage is most severe in the liver and less severe in the kidney and gastrointestinal tract (Zurawell and others, 2005; Malbrouck and Kestemont, 2006). Microcystins affect tissues by binding with protein phosphatases 1 and 2A (PPs) that are critical to maintaining cell wall architecture (Tencalla and Dietrich, 1997; Zurawell and others, 2005). In toxic concentrations, microcystins cause cell walls to leak and lead to death by hypovolemic shock (Zurawell and others, 2005). Tissue damage appears in histological sections as necrosis and severe intracellular hemorrhaging (Tencalla and Dietrich, 1997; Zurawell and others, 2005).

Limited evidence indicates potential dietary exposure of Lost River suckers in Upper Klamath Lake to microcystins. Foott and others (2014) documented PP suppression, but a lack of cellular damage, to the livers in sentinel young-of-year suckers held in Upper Klamath Lake for 7-14 days. This finding is consistent with sub-lethal exposure to microcystin; however, exposure in net-pen confined fish may be enhanced due to direct feeding on the accumulation of debris on the nets. Tissue damage due to acute sub-lethal concentrations in fish is reversible given enough time (Malbrouck and others, 2003). Ibelings and Haven (2008) suggest that partial recovery can occur within days, while Malbrouck and others (2003) found it took goldfish (Carassius auratus) 21 days for the hepatocytes in the liver to fully recover. Therefore, liver histopathology cannot be used as a reliable bioindicator of past exposure to cyanotoxins in wild fish, because the damage to the liver is transient and recovery from liver damage is rapid (Ibelings and Havens, 2008). Only fish recently exposed to microcyst in would still show signs of liver damage through histology. As such, it cannot be determined if the lack of histopathological damage observed by Foott and others (2014) was due to a lack of effect or if fish had already recovered from the effect. Because microcystin exposure can be higher in net pens than for wild populations due to the cyanobacteria accumulating on the net, the Foott and others (2014) results may represent an unnatural occurrence (Anderson and others, 1993). Similar PP enzyme suppression or other indications of microcystin toxicity have not been found in wild juvenile suckers from Upper Klamath Lake (Burdick and others, 2015 and 2017; Janik and others, 2018). It remains unknown if wild juvenile suckers could be affected by microcystin and what concentrations would cause lethal or sub-lethal effects.

Orally administered concentrations of pure or crude cell extracts of microcystins can produce sub-lethal or lethal effects that vary widely among studies on different fishes. Median lethal doses of microcystin delivered as lysed whole cells of $M$. aeruginosa range from 1,700 $\mu \mathrm{g} / \mathrm{kg}$ bm within 72-96 $\mathrm{h}$ for common carp to $6,600 \mu \mathrm{g} / \mathrm{kg}$ bm within 24-72 $\mathrm{h}$ for rainbow trout (Fischer and Dietrich, 2000). The highest sub-lethal dose that we could find in the literature was $20,000 \mu \mathrm{g} / \mathrm{kg}$ of pure MC-LR delivered to channel catfish (Ictalurus punctatus) (Snyder and others 2002). This high dose was associated with severe liver damage in the channel catfish. Assuming suckers are exposed to microcystins by feeding at the sediment-water interface (VanderKooi and others, 2010), that they feed exclusively on newly deposited sediments that include cyanobacteria and that they feed at a rate of 2 percent body mass (bm) per day (Martin, 2018), a mid-summer exposure to $38.2 \mu \mathrm{g} / \mathrm{g}$ (Caldwell Eldridge and others, 2013) would result in a daily dose of up to $764 \mu \mathrm{g} / \mathrm{kg} /$ day for a $1 \mathrm{~g}$ sucker. Given the one-time maximum observed 
concentration of microcystin in newly deposited sediments of 1,107 $\mu \mathrm{g} / \mathrm{g}$ (Caldwell Eldridge and others, 2013), the dose could be as high as $22,140 \mu \mathrm{g} / \mathrm{kg} /$ day. Lost River suckers, however, don't appear to feed directly on M. aeruginosa and are more likely to obtain microcystin as secondary consumers (VanderKooi and others, 2010).

Microcystin appears to biodilute through the food chain, further decreasing suckers' potential exposure to the toxin (Iberlings and others, 2005; Kozlowsky-Suzuki and others, 2012). For example, Kotak and others (1996) reported that microcystins were transferred from phytoplankton to zooplankton to benthic invertebrates, but due to biodilution not to northern pike (Esox lucius) and white sucker (Catostomus commersoni) that consumed the invertebrates. Given that exposure path to Lost River suckers has one fewer trophic level (M. aeruginosa $>$ chironomid larvae>suckers), Lost River suckers may still receive a dose of microcystin through their diet, but the dose would likely be much lower than if they fed directly on M. aeruginosa. It is, therefore, difficult to determine an environmentally relevant dose of microcystin to which suckers may be exposed through consumption of invertebrates. However, the food web route of exposure indicates that a pure toxin, free of secondary effects of M. aeruginosa cells themselves, is relevant. In this study we quantify the concentrations of pure MC-LR that could induce sublethal or lethal effects on juvenile Lost River suckers.

\section{Methods}

\section{Experimental fish}

The U.S. Fish and Wildlife Service (USFWS) California-Nevada (CA-NV) Fish Health Center propagated fish for this study. Eggs and milt were harvested from wild adult Lost River suckers captured during the spawning seasons of 2013 and 2015 at Sucker Springs in Upper Klamath Lake. Eggs were fertilized lake-side and then transported to USFWS CA-NV Fish Health Center for rearing. Juvenile fish, approximately 6 months old, were then transferred to the Klamath Tribes Hatchery in Chiloquin, Oregon, for experimental trials. Fish were kept in 1,136$\mathrm{L}$ round tanks that were on a recirculation system with constant aeration to each tank. To ensure proper rearing conditions for the fish, temperature, $\mathrm{pH}$, conductivity and dissolved oxygen were monitored hourly using a YSI 600XLM continuous monitoring Sonde (YSI instruments, Yellow Springs Ohio), while ammonia and nitrates were monitored daily using Tetra EasyStrips ${ }^{\mathrm{TM}}$ (Tetra, Blacksburg, Virginia). Fish were fed a maintenance or growth ration of Otohime (Reed Mariculture, Campbell, California) pellets of various sizes (B1, B2, C1, C2, S2, EP-1) depending on the size of the fish until the fish were used in toxicity trials. We used fish that were of similar size as young-of-year Lost River suckers in mid-summer in Upper Klamath Lake (around 45-90 millimeter [mm] standard length; Burdick and Martin, 2017). Fish were selected to be of a similar size within each trial to reduce any size related effects within treatment groups (table 1). 
Table 1. List of microcystin trials performed and vital statistics on the fish used for those trials.

[Mean standard length, mass, and temperature are followed by standard errors. SL: Standard length of fish. Abbreviations: g, gram; mm, millimeter; $\mathrm{N}$, total number of fish examined; ${ }^{\circ} \mathrm{C}$, degrees Celsius]

\begin{tabular}{lllllccc}
\hline Trial & \multicolumn{1}{c}{$\begin{array}{c}\text { Trial } \\
\text { type }\end{array}$} & \multicolumn{1}{c}{$\begin{array}{c}\text { Trial } \\
\text { date }\end{array}$} & $\begin{array}{c}\text { Cohort } \\
\text { used }\end{array}$ & N & $\begin{array}{c}\text { SL } \\
(\mathbf{m m})\end{array}$ & $\begin{array}{c}\text { mass } \\
(\mathbf{g})\end{array}$ & $\begin{array}{c}\text { Temperature } \\
\left({ }^{\circ} \mathbf{C}\right)\end{array}$ \\
\hline 1 & Single feeding & April 2014 & 2013 & 80 & $82 \pm 3$ & $7.4 \pm 0.5$ & $15.5 \pm 0.8$ \\
2 & Single feeding & June 2014 & 2013 & 80 & $83 \pm 3$ & $7.4 \pm 0.6$ & $17.3 \pm 1.6$ \\
3 & Single feeding & May 2016 & 2015 & 80 & $60 \pm 2$ & $2.9 \pm 0.3$ & $18.4 \pm 0.7$ \\
4 & Chronic feeding & June 2016 & 2015 & 80 & $62 \pm 2$ & $3.1 \pm 0.2$ & $18.1 \pm 1.0$ \\
5 & Chronic feeding & September 2016 & 2015 & 40 & $61 \pm 2$ & $2.9 \pm 0.2$ & $15.4 \pm 1.2$ \\
\hline
\end{tabular}

\section{Evaluation of Toxin Delivery Methods}

Before starting trials with microcystin, we experimented with using gavage (ground midge larvae slurry and pure liquid) and direct feeding of different types of food (ground midge larvae, food pellets and both types of diets encased in gelatin) to find an adequate method for toxin delivery. It appeared that gavaging colored liquid through a microsyringe was successful, while gavaging a slurry of ground midge larvae mixed with colored water was not successful. The slurry was too thick to pass through the tip of the micropipettors and if a tip was large enough to pass the slurry then it was too large to fit in the fish mouth. Fish kept in individual plastic buckets could be observed to completely consume commercial fish pellets at 0.5 percent of bm; however, the same was not true for diets of ground midge larvae with or without gelatin. The ground midge larvae diets were too fine for us to observe consumption by fish. Fish offered pellets at 1 percent of bm did not consume all the pellets within 24 hours (h). Initially, we suspected gavage of a liquid to be the best method for us to administer a complete dose at a known time. Feeding fish spiked food pellets at 0.5 percent of bm was our second choice since we had concerns about our ability to guarantee that the fish would consume the complete dose and that timing of consumption might vary among test subjects.

A total of 80 Lost River suckers (mean $79 \pm 7$ mm standard length) were gavaged with 0 $20 \mu \mathrm{g}$ of purified MC-LR (Cayman Chemical, Co., Ann Arbor, Michigan) in $50 \mu \mathrm{L}$ of distilled water colored with red food dye, using a microsyringe with a blunt electro-polished tip (Hamilton, Reno, Nevada). After each fish was subjected to gavage, it was placed alone in a plastic recovery bucket and observed for 2 minutes. Approximately 25 percent of fish visibly expelled the colored liquid containing the toxin through their gills or mouth. No fish died after $96 \mathrm{~h}$ or had histological abnormalities. To determine if microcystin was making it into the sucker digestive systems, we gavaged several Lost River suckers with a contrast tracer (Gastrografin ${ }^{\circledR}$, Bayer, Leverkusen, Germany) and immediately x-rayed them at Oregon Institute of Technology, Klamath Falls, Oregon. The x-rays indicated that the liquid was pooling in the fish's mouth and not penetrating past the esophageal sphincter, confirming that the microcystin did not enter the gut of our test subjects. Furthermore, we determined that the outside diameter of the syringe was larger than the inside diameter of the esophagus leading to internal damage of the esophagus if the syringe was inserted past the esophageal sphincter. Based on this information we determined that the use of gavage for administrating microcystin into the guts of Lost River suckers of this size would not work.

The next method of toxin delivery that we tried was to feed suckers uncoated and gelatin (commercial Knox brand; TreeHouse Foods, Oak Brook, Illinois) coated pellets. Most Lost 
River suckers consumed a meal composed of Otohime (Reed Mariculture, Campbell, California) $\mathrm{S} 2$ pellets at 0.5 percent of bm within $24 \mathrm{~h}$. A leaching study was conducted to address the concern that microcystin could be lost from pellets into the water. Test diets consisted of $40 \mathrm{mg}$ of Otohime S-2 food either spiked with $10 \mu \mathrm{g}$ MC-LR, prepared using methods below, or unspiked (control diets). Five of these diets were coated in gelatin according to methods below and three diets were not coated. Each test and control diet was allowed to soak in $5 \mathrm{~mL}$ of ultrapurified water (Millipore Milli-Q) at room temperature. Subsamples $(100 \mu \mathrm{L})$ of the overlying water were tested for microcystin using Enzyme-linked immunosorbent assay (ELISA) at 0 h, 1 h, $2 \mathrm{~h}, 4 \mathrm{~h}, 6 \mathrm{~h}, 8 \mathrm{~h}$ and $24 \mathrm{~h}$. Less than 1 percent of the microcystin leached out of both food types after $24 \mathrm{~h}$ of soaking in deionized water (table 2). Consequently, it was determined that feeding spiked pellets could administer the MC-LR successfully.

Table 2. Amount of MC-LR that leached from pelleted S-2 food soaked in deionized water for 24 hours. [Abbreviations: MC-LR, microcystin-LR; mg, milligram; $\mathrm{ng} / \mathrm{mL}$, nanogram per milliliter; $\mu \mathrm{g}$, microgram]

\begin{tabular}{llcccc}
\hline $\begin{array}{l}\text { Diet identification } \\
\text { No. }\end{array}$ & Treatment description & $\begin{array}{l}\text { Mass of test } \\
\text { diet }(\mathbf{m g})\end{array}$ & $\begin{array}{c}\text { MC-LR in } \\
\text { test diet }(\boldsymbol{\mu g})\end{array}$ & $\begin{array}{c}\text { MC-LR in water } \\
(\mathbf{n g} / \mathbf{m L})\end{array}$ & $\begin{array}{c}\text { Percent loss } \\
\text { of MC-LR }\end{array}$ \\
\hline 1 & Gelled with MC-LR & 42.2 & 10 & 17.74 & 0.89 \\
2 & Gelled with MC-LR & 41.4 & 10 & 17.99 & 0.90 \\
3 & Gelled with MC-LR & 40.0 & 10 & 17.62 & 0.88 \\
4 & Gelled with MC-LR & 42.0 & 10 & 18.05 & 0.90 \\
5 & Gelled no MC-LR & 41.5 & 0 & 1.44 & NA \\
6 & Not Gelled no MC-LR & 40.6 & 0 & 0.12 & NA \\
7 & Not Gelled with MC-LR & 40.4 & 10 & 17.14 & 0.86 \\
8 & Not Gelled with MC-LR & 40.3 & 10 & 17.44 & 0.87 \\
\hline
\end{tabular}

Preparation of Diets

Otohime EP-1 (Trials 1 and 2) or S-2 (Trials 3, 4, and 5) pellet food was spiked with MCLR. Totals of $1.0 \mathrm{~g}$ (Trials 1 and 2), $0.3 \mathrm{~g}$ (Trial 3), $3.0 \mathrm{~g}$ (Trial 4), and $1.5 \mathrm{~g}$ (Trial 5) of food was spiked per dose creating enough feeding portions plus a few extra for each fish per dose per trial. A feeding portion of EP-1 pellets was $40 \mathrm{mg}$ while a feeding portion of S-2 pellets was 10 mg. Concentrations of microcystin per fish per trial were based on feeding portions, so that each feeding portion would deliver the expected dose of microcystin (tables 3 and 4). Verification of concentrations per feeding dose was conducted for each feeding dose for each trial by analyzing these feeding portions via high-performance liquid chromatography (HPLC). To ensure complete consumption of food and associated toxin, portions of food were based on an estimate of 0.5 percent of bm of the expected size of the fish to be used in the trials. Fish that did not consume all the food within $24 \mathrm{~h}$ were dropped from the study. Smaller pellets (Otomine S-2) and feeding doses were use in Trials 3, 4, and 5 because they were intended for smaller fish. Estimated body burdens were calculated by the following equation: (Dose per fish $(\mu \mathrm{g}) / \mathrm{mass}(\mathrm{g}))^{*} 1,000 \mathrm{~g} / \mathrm{kg}$. 
Table 3. Microcystin dose per fish used in single dose trials and resulting estimated body burden.

[Food pellets delivered were either uncoated or gelatin coated. Mean ( \pm standard error) standard length and mass, of Lost River suckers used are given. Mean ( \pm standard error) estimated body burdens for the entire trial are given. Abbreviations: g, gram; N, total number of fish examined; SL, standard length of fish; $\mu \mathrm{g}$, microgram; $\mu \mathrm{g} / \mathrm{kg}$, microgram per kilogram]

\begin{tabular}{ccccccc}
\hline Trial & $\begin{array}{c}\text { Pellet } \\
\text { type }\end{array}$ & $\begin{array}{c}\text { Dose/fish } \\
(\boldsymbol{\mu g})\end{array}$ & $\mathbf{N}$ & SL $(\mathbf{m m})$ & mass $\mathbf{( g )}$ & $\begin{array}{c}\text { Body burden } \\
(\boldsymbol{\mu g} / \mathbf{k g} \text { biomass })\end{array}$ \\
\hline 1 & Uncoated & 0 & 20 & $83 \pm 3$ & $7.3 \pm 0.65$ & 0 \\
1 & Uncoated & 10 & 20 & $82 \pm 3$ & $7.4 \pm 0.59$ & $1,400 \pm 110$ \\
1 & Uncoated & 20 & 20 & $82 \pm 2$ & $7.4 \pm 0.50$ & $2,700 \pm 200$ \\
1 & Uncoated & 30 & 20 & $82 \pm 3$ & $7.4 \pm 0.42$ & $4,100 \pm 230$ \\
2 & Uncoated & 0 & 20 & $82 \pm 3$ & $7.1 \pm 0.21$ & 0 \\
2 & Uncoated & 30 & 20 & $80 \pm 2$ & $6.7 \pm 0.21$ & $4,500 \pm 150$ \\
2 & Uncoated & 60 & 20 & $85 \pm 2$ & $7.7 \pm 0.22$ & $7,800 \pm 220$ \\
2 & Uncoated & 90 & 20 & $86 \pm 2$ & $8.1 \pm 0.26$ & $11,000 \pm 360$ \\
3 & Coated & 0 & 20 & $62 \pm 2$ & $3.3 \pm 0.05$ & 0 \\
3 & Coated & 36 & 20 & $58 \pm 1$ & $2.5 \pm 0.05$ & $14,000 \pm 270$ \\
3 & Coated & 48 & 20 & $59 \pm 2$ & $2.8 \pm 0.09$ & $17,000 \pm 570$ \\
3 & Coated & 60 & 20 & $60 \pm 1$ & $3.0 \pm 0.04$ & $20,000 \pm 290$ \\
\hline
\end{tabular}

Table 4. Microcystin daily dose per fish in chronic feeding trials and resulting estimated daily and total body burden.

[Food pellets delivered were all gelatin coated. Mean ( \pm standard error) standard length and mass of Lost River suckers used are given. Mean ( \pm standard error) estimated body burdens for the entire trial are given.

Abbreviations: g, gram; mm, millimeter; N, total number of fish examined; SL, standard length of fish; $\mu \mathrm{g}$, microgram; $\mu \mathrm{g} / \mathrm{kg}$, microgram per kilogram]

\begin{tabular}{ccccccccc}
\hline Trial & $\begin{array}{c}\text { Pellet } \\
\text { type }\end{array}$ & $\begin{array}{c}\text { Daily } \\
\text { dose/fish } \\
(\boldsymbol{\mu g})\end{array}$ & $\begin{array}{c}\text { 14-day } \\
\text { total } \\
\text { dose/fish } \\
(\boldsymbol{\mu g})\end{array}$ & $\mathbf{N}$ & $\mathbf{S L}(\mathbf{m m})$ & mass $\mathbf{( g )}$ & $\begin{array}{c}\text { Daily body burden } \\
(\boldsymbol{\mu g} / \mathbf{k g} \text { biomass })\end{array}$ & $\begin{array}{c}\text { 14-day total body } \\
\text { burden }(\boldsymbol{\mu g} / \mathbf{k g} \\
\text { biomass })\end{array}$ \\
\hline 4 & Coated & 0 & 0 & 20 & $63 \pm 2$ & $3.4 \pm 0.05$ & 0 & 0 \\
4 & Coated & 5 & 70 & 20 & $62 \pm 2$ & $3.0 \pm 0.04$ & $1,700 \pm 26$ & $24,000 \pm 360$ \\
4 & Coated & 10 & 140 & 20 & $62 \pm 1$ & $3.2 \pm 0.05$ & $3,200 \pm 52$ & $44,000 \pm 1500$ \\
4 & Coated & 20 & 280 & 20 & $60 \pm 2$ & $2.7 \pm 0.09$ & $7,300 \pm 250$ & $103,000, \pm 3500$ \\
5 & Coated & 0 & 0 & 10 & $63 \pm 1$ & $3.2 \pm 0.05$ & 0 & 0 \\
5 & Coated & 20 & 280 & 10 & $60 \pm 1$ & $2.7 \pm 0.00$ & $7,400 \pm 0$ & $104,000 \pm 0$ \\
5 & Coated & 40 & 560 & 10 & $61 \pm 1$ & $2.8 \pm 0.03$ & $14,000 \pm 170$ & $201,000 \pm 2300$ \\
5 & Coated & 60 & 840 & 10 & $62 \pm 2$ & $3.0 \pm 0.05$ & $20,000 \pm 360$ & $290,000 \pm 9700$ \\
\hline
\end{tabular}

Three $\mathrm{mg}$ of MC-LR was diluted to $1 \mathrm{ml}$ in 1:1 ethanol/methanol for dosing EP-1 food for Trials 1 and 2 to make a stock solution, whereas $1 \mathrm{mg}$ stock solution of MC-LR was concentrated in ethanol for dosing S-2 food for Trials 3, 4, and 5. The methods were changed between trials 2 and 3 due to concerns with toxicity of methanol to the fish. The change was an extra precaution, since there was complete evaporation and there should not have been any methanol remaining. The solutions of MC-LR with ethanol/methanol (EP-1 food) or ethanol only 
(S-2 food) were added to food portions by Pasteur pipet to create spiked foods with appropriate doses (tables 3 and 4). After the food was spiked $0.1 \mathrm{ml}$ ethanol was used to rinse the vial once (EP-1 food) or twice (S-2 food) and added to the respective diets. EP-1 diets were allowed to stand $2 \mathrm{~h}$ to allow the MC-LR to absorb to the diet and then were heated to $80{ }^{\circ} \mathrm{C}$ on a heating block under a nitrogen stream to evaporate the ethanol. The S-2 diets were allowed to sit at room temperature for 18 to $23 \mathrm{~h}$ to allow the MC-LR to absorb to the diet and ethanol to evaporate. To determine if any of the MC-LR remained on the glass, the contents of the vial were decanted into a clean vial, and $160 \mu \mathrm{L}$ of water were added to the original vial (enough to cover the bottom of the vial) and allowed to sit in the vial for an hour. The water was transferred to a $0.3 \mathrm{~mL}$ autosampler vial and injected on the HPLC, which indicated that only 0.05 percent of the amount of MC-LR remained in the vial after decanting. The S-2 diet was coated with $400 \mu \mathrm{L}$ of the hot gelatin solution ( $4 \mathrm{~mL}$ near boiling water mixed with $130 \mathrm{mg}$ of commercial Knox gelatin) stirred into the dosed food pellets and placed overnight into a $4{ }^{\circ} \mathrm{C}$ refrigerator.

\section{Feeding Trials}

We conducted three single-dose feeding trials and two chronic feeding trials with progressively higher concentrations of MC-LR (tables 3 and 4). Given our difficulty determining an environmentally relevant dose for juvenile Lost River suckers we used literature to guide our decision on doses used in this study. Doses used in Trial 1 were chosen to exceed levels previously demonstrated to cause significant liver damage to common carp ( $400 \mu \mathrm{g} / \mathrm{kg})$ and be within ranges observed to be lethal within 24 to $72 \mathrm{~h}$ to rainbow trout $(6,600 \mu \mathrm{g} / \mathrm{kg})$ and common carp $(1,700 \mu \mathrm{g} / \mathrm{kg}$; Fischer and Dietrich, 2000). These toxicities were observed when both species were gavaged with a slurry of lysed whole cells of $M$. aeruginosa. In Trial 2 we choose our low dose to exceed our high dose in Trial 1. Similarly, the low dose in Trial 3 was higher than the high dose in Trial 2. We set an upper limit for doses to administer in Trial 3 at 20,000 $\mu \mathrm{g} / \mathrm{kg}$ based on observations of Snyder and other (2002). They found that gavaging channel catfish (Ictalurus punctatus) with $20,000 \mu \mathrm{g} / \mathrm{kg}$ of pure MC-LR resulted in no deaths but histopathological damage was observed $48 \mathrm{~h}$ post gavage. This dose was similar to the estimated maximum dose $(22,140 \mu \mathrm{g} / \mathrm{kg} /$ day $)$ we predicted wild Lost River suckers could obtain if they were to exclusively feed on $M$. aeruginosa.

We conducted two chronic feeding trails (Trials 4 and 5) to determine lethal and sublethal effects of orally acquired microcystin toxin. The daily concentrations chosen in our first chronic trial were based on a range that encompassed concentrations used in the first two singledose trials (Trials 1 and 2), while the second chronic trial encompassed a range of the last two single-dose feeding trials (Trials 2 and 3). A 2-week duration was chosen based on the duration of microcystin blooms in Upper Klamath Lake (Eldridge and others, 2012).

A total of 80 fish were divided among four treatments with 20 fish per treatment in each trial, except for the high dose chronic feeding trial (table 1). Due to the high cost of MC-LR, only 40 fish were divided among 4 treatments with 10 fish per treatment in the high dose chronic feeding trial (table 1). Every trial included a control group and three treatments with dosed food. At the start of each experiment, fish were weighed, measured and placed into individual 5-gallon plastic square buckets with stainless steel wire mesh bottoms hung in larger plastic tanks within a recirculating system. There were 10 buckets hung in each of the 568-L plastic tanks with constant aeration. To ensure proper experimental conditions for the fish, temperature, $\mathrm{pH}$, conductivity and dissolved oxygen were monitored hourly using a YSI 600XLM continuous monitoring Sonde (YSI instruments, Yellow Springs, Ohio), while ammonia and nitrates were 
monitored daily using Tetra EasyStrips ${ }^{\mathrm{TM}}$ (Tetra, Blacksburg, Virginia). Fish were starved for 24 $\mathrm{h}$, then all feces were removed from the cages before the spiked diet was introduced. Although starving the fish for $24 \mathrm{~h}$ may increase the initial uptake of microcystin in the cells, the overall uptake after $24 \mathrm{~h}$ is likely the same (Malbrouck and others, 2004). Fish were monitored daily for consumption of food and potential health problems. Procedures were the same in chronic feeding trials, except that feces were removed daily before offering a daily ration. Immediately after the first trial was completed, an additional two fish per concentration were fed spiked diets from left over feeding portions from Trial 1; these fish were euthanized after $24 \mathrm{~h}$. All other fish were euthanized either $96 \mathrm{~h}$ after ingestion in single dose trials 1 and 2 or $24 \mathrm{~h}$ after the ingestion of last feeding in single dose trial 3 and chronic feeding trials 4 and 5. Fish euthanized at the end of each trial were either preserved in 10 percent phosphate buffered formalin for histology or frozen for microcystin determination. Histology was performed on five fish from each concentration from each trial, including controls. Furthermore, five fish from each high dose treatment in each trial, except Trial 2 with ten fish, were examined for immunohistochemical staining of MC-LR. In each trial, five negative controls were also examined. The remaining fish that were preserved for histology were kept as auxiliary samples. Due to processing issues, varying numbers of fish were processed for microcystin analysis.

\section{Histological Examination}

Tissues including gill, heart, kidney, liver, spleen, and gastrointestinal tract were processed and embedded in paraffin wax. Four-micrometer serial sections were stained with hematoxylin and eosin to evaluate any histopathological changes. For immunohistochemical detection of microcystin antigen, a procedure adapted from Foott and others (2012) was used with the following changes: endogenous alkaline phosphatase was quenched using Bloxall ${ }^{\circledR}$ blocking solution (Vector Laboratories, Burlingame, California), a monoclonal antibody to MCLR (MC10E7, Enzo Life Sciences, Farmingdale, New York) was diluted 1:800 volume/volume (1.25 ng $\mu \mathrm{L}-1)$ in 2.5 percent normal goat serum (Vector Laboratories) and visualized with Mach2TM alkaline phosphatase detection and Vulcan Fast Red chromogen kit (Biocare Medical, Pacheco, California) according to the manufacturer's instructions.

\section{Microcystin Tissue Analysis}

Unbound microcystin was extracted from each whole fish by use of the sonication method described by Guo and others (2014). We used a modified method of the Echols and Jones (2005) HPLC/UV methodology. The analysis was carried out by automated injections on a Dionex (Thermo Scientific, Waltham, Massachusetts) Ultimate 3000 HPLC Chromatography System. The column used was a 100 x $4.6 \mathrm{~mm}$ Phenomenex Kinetex PFP $(2.6 \mu \mathrm{m}, 100$ angstroms) with a Rheodyne $2 \mu \mathrm{m}$ particle filter attached to the inlet of the column. The column was held at $35^{\circ} \mathrm{C}$ during the analysis. The analysis was by UV detection via a diode array detector monitoring wavelength 238 nanometers for the microcystins. The mobile phase was A: 0.05 percent trifluoroacetic acid in methanol, B: 0.05 percent trifluoroacetic acid in Millipore 18 megaohms of water. There were no matrix effects since there was extensive clean up with a 23 minute HPLC method that cleanly separated the free MC-LR analyzed from interferences and other MC analogs. Reporting limits were at $0.2 \mu \mathrm{g} / \mathrm{g}$ of tissue and replicates had a standard deviation of zero for these samples. Data analysis of comparisons of the percent microcystin recovered at different concentrations was performed using the non-parametric Kruskal-Wallis test because the data did not meet the assumptions of the parametric analysis of variance test. 


\section{Results}

Trial 1

During Trial 190 percent of the fish consumed the food within the first $24 \mathrm{~h}$, while 9 percent consumed the food within $48 \mathrm{~h}$. A single fish from the control group did not consume the allotted food during the trial. No mortality occurred during the 96-h observation period. Histology results indicated no differences between the controls and fish fed microcystin-spiked foods at the two lower doses (10 and $20 \mu \mathrm{g}$ of MC-LR) and larger fish (greater than or equal to $7.7 \mathrm{~g}$ ) given $30 \mu \mathrm{g}$ of MC-LR. However, the smaller fish (less than or equal to $7.3 \mathrm{~g}$ ) given $30 \mu \mathrm{g}$ of MC-LR showed cellular changes consisting of slightly enlarged hepatocytes. These changes only occurred in fish given a dose resulting in an estimated body burden greater than 4,000 $\mu \mathrm{g} / \mathrm{Kg}$ biomass, but affected less than 10 percent of the hepatocytes examined in liver tissue sections from a given fish. Only one out of the five fish examined from the highest dose group (30 $\mu \mathrm{g}$ of MC-LR) via immunohistochemical staining of MC-LR had a positive reaction for MCLR antigen in the epithelial tissue and digestive contents of the posterior intestine (table 5). This fish had the highest estimated body burden $(4,478 \mu \mathrm{g} / \mathrm{kg})$ based on microcystin dose per mass of the fish. Free MC-LR was found in tissues of fish exposed to all concentrations of microcystin (table 6). However, less than 2 percent of the introduced microcystin was detected in assays for unbound MC-LR. Fish tested $24 \mathrm{~h}$ after food ingestion had higher percentages of unbound microcystin in their tissues than those examined $96 \mathrm{~h}$ after ingestion.

Table 5. Numbers of Lost River suckers showing positive results for the presence of microcystin antigen by immunohistochemical testing.

[Only control fish and fish receiving the highest doses of MC-LR within each feeding trial were tested. No control fish showed positive immunohistochemical staining for the microcystin antigen. Abbreviations: N, total number of fish examined; $\mu \mathrm{g}$, microgram]

\begin{tabular}{|c|c|c|c|c|c|c|c|c|}
\hline \multirow[t]{2}{*}{ Trial } & \multirow[t]{2}{*}{$\mathbf{N}$} & \multirow{2}{*}{$\begin{array}{c}\text { Cumulative } \\
\text { dose }(\mu \mathrm{g})\end{array}$} & \multirow{2}{*}{$\begin{array}{c}\text { Holding } \\
\text { time after } \\
\text { last } \\
\text { ingestion of } \\
\text { food } \\
\text { (hours) }\end{array}$} & \multirow[t]{2}{*}{ Liver } & \multicolumn{2}{|c|}{ Upper intestine } & \multicolumn{2}{|c|}{ Lower intestine } \\
\hline & & & & & $\begin{array}{l}\text { Epithelial } \\
\text { cells }\end{array}$ & $\begin{array}{l}\text { Digestive } \\
\text { contents }\end{array}$ & $\begin{array}{l}\text { Epithelial } \\
\text { cells }\end{array}$ & $\begin{array}{l}\text { Digestive } \\
\text { contents }\end{array}$ \\
\hline 1 & 5 & 30 & 96 & 0 & 0 & 0 & 1 & 1 \\
\hline 2 & 10 & 90 & 96 & 5 & 0 & 4 & 4 & 5 \\
\hline 3 & 5 & 60 & 24 & 5 & 1 & 2 & 5 & 3 \\
\hline 4 & 5 & 280 & 24 & 5 & 1 & 2 & ${ }^{1} 4$ & 4 \\
\hline 5 & ${ }^{2} 5$ & 840 & 24 & 4 & 3 & 3 & 5 & 5 \\
\hline
\end{tabular}

${ }^{1}$ Severe autolysis in the epithelium of one fish; unable to determine if an immunohistochemical reaction was present.

${ }^{2}$ One liver not sectioned. 
Table 6. Average amount (standard deviation) of MC-LR recovered in whole fish following single dose feeding trials, shown by dose and holding time after ingestion.

[Abbreviations: $\mathrm{N}$, total number of fish examined;,$- \mu \mathrm{g}$, microgram; no percentage to be recovered since no initial MC-LR]

\begin{tabular}{clrrcl}
\hline Trial & $\begin{array}{c}\text { Time } \\
\text { (hours) }\end{array}$ & $\begin{array}{c}\text { Dose } \\
(\boldsymbol{\mu g})\end{array}$ & $\mathbf{N}$ & $\begin{array}{c}\boldsymbol{\mu} \text { g of free } \\
\text { MC-LR } \\
\text { recovered }\end{array}$ & $\begin{array}{c}\text { Percentage of initial } \\
\text { MC-LR recovered in } \\
\text { the free state }\end{array}$ \\
\hline 1 & 24 & 0 & 1 & 0 & - \\
1 & 24 & 10 & 1 & 0.19 & 1.88 \\
1 & 24 & 20 & 1 & 0.18 & 0.89 \\
1 & 24 & 30 & 1 & 0.54 & 1.80 \\
1 & 96 & 0 & 4 & 0 & - \\
1 & 96 & 20 & 1 & 0.03 & 0.13 \\
1 & 96 & 30 & 10 & $0.09(0.06)$ & $0.29(0.21)$ \\
3 & 24 & 0 & 5 & 0 & - \\
3 & 24 & 36 & 5 & $0.11(0.02)$ & $0.31(0.06)$ \\
3 & 24 & 48 & 5 & $0.03(0.01)$ & $0.07(0.02)$ \\
3 & 24 & 60 & 5 & $0.03(0.01)$ & $0.06(0.01)$ \\
\hline
\end{tabular}

Trial 2

All fish in Trial 2 consumed the allotted food within the first $24 \mathrm{~h}$. No fish died during the $96 \mathrm{~h}$ of observation; however, fish in the highest dose group appeared more agitated, swimming erratically. The different doses resulted in estimated total body burdens ranging from $4,300 \mu \mathrm{g} / \mathrm{kg}$ toxin/biomass to $12,000 \mu \mathrm{g} / \mathrm{kg}$ toxin/biomass. No histological abnormalities were detected. Positive immunohistochemical staining for MC-LR antigen was found in 40-50 percent of the fish given the highest dose and were limited to the epithelial cells and digestive contents of the posterior intestine, the digestive contents of the anterior intestine, and the liver (table 5). However, the reaction in the liver tissue was weak compared to the intestinal sites, based on the intensity of the color change.

Trial 3

Doses delivered in Trial 3 yielded estimated body burdens of 14,000-20,000 $\mu \mathrm{g} / \mathrm{kg}$ biomass (table 3). All but one fish (a control) consumed the allotted food within $24 \mathrm{~h}$. The one fish that did not consume its food was found dead $24 \mathrm{~h}$ after being offered food. Most of the fish (76 percent) consumed their food within $2 \mathrm{~h}$ after feeding. Consequently, it was assumed that each fish received the intended dose. Histopathological results indicated no abnormalities associated with microcystin exposure. In the lower intestine, microcystin antigen was present in the epithelial cells of all fish and in the digestive contents of 60 percent of fish. Positive immunohistochemical staining was also observed in the upper intestine epithelium and digestive contents of 20 percent and 40 percent of fish, respectively. Less intense positive staining was also observed in the livers of all fish examined (table 5). Free MC-LR was detected from whole body samples in all the exposed fish; however, the lowest concentration yielded the highest percentage of free MC-LR recovered (table 6), which was significantly different from the 
percentage recovered from the other two concentrations (Kruskal-Wallis $\chi^{2}=9.38$, degrees of freedom $[\mathrm{df}]=2, \mathrm{p}=0.009$ ). Less than 1 percent of the microcystin delivered was recovered in the free state in any of the fish.

Trial 4

In Trial 4, cumulative doses ranging from 70 to $280 \mu \mathrm{g}$ of MC-LR were fed to the fish, resulting in estimated total body burdens of 23,000-108,000 $\mu \mathrm{g} / \mathrm{kg}$ bio mass if all of the microcystin was incorporated into the body (table 4). Most fish (94 percent) had an average consumption time of $2 \mathrm{~h}$ or less. Only 1 fish did not consume its entire dose, skipping 2 of the 14 meals. There were no histopathological abnormalities associated with microcystin exposure. Immunohistochemical analysis showed positive staining in the lower intestine epithelial cells and digestive contents of 80 percent of fish and in the upper intestine epithelium and digestive contents of 20 percent and 40 percent of fish, respectively. All fish showed a weakly positive immunohistochemical reaction in the liver (table 5). Unlike the single dose studies, the first chronic dose study resulted in recovery of progressively more free microcystin in fish as the doses increased (table 7); however, there was no significant difference in percentage of free MCLR recovered (Kruskal-Wallis $\chi^{2}=4.46, \mathrm{df}=2, \mathrm{p}=0.108$ ). Less than 1 percent of the delivered microcystin was recovered in the free state in any of the fish.

Table 7. Average amount (standard deviation) of MC-LR recovered in fish during chronic trials (Trials 4 and 5) 24 hours after ingestion of the last meal.

[Abbreviations: N, total number of fish examined; $\mu \mathrm{g}$, microgram; $(\mu \mathrm{g}) /$ day, microgram per day; $(\mu \mathrm{g}) / \mathrm{study}$, microgram per study; -, no percentage to be recovered since no initial MC-LR]

\begin{tabular}{rcclll}
\hline Trial & $\begin{array}{c}\text { Dose } \\
(\boldsymbol{\mu g}) / \text { day }\end{array}$ & $\begin{array}{c}\text { Dose } \\
(\boldsymbol{\mu g}) / \mathbf{s t u d y}\end{array}$ & $\mathbf{N}$ & $\begin{array}{c}\boldsymbol{\mu} \text { o of free MC-LR } \\
\text { recovered }\end{array}$ & $\begin{array}{c}\text { Percent of initial MC-LR } \\
\text { recovered in the free state }\end{array}$ \\
\hline 4 & 0 & 0 & 5 & 0 & - \\
4 & 5 & 70 & 5 & $0.35(0.19)$ & $0.01(0.01)$ \\
4 & 10 & 140 & 5 & $0.44(0.32)$ & $0.03(0.02)$ \\
4 & 20 & 280 & 5 & $1.73(1.15)$ & $0.02(0.02)$ \\
5 & 0 & 0 & 5 & 0 & - \\
5 & 40 & 560 & 5 & $0.75(0.49)$ & $0.13(0.09)$ \\
5 & 60 & 840 & 5 & $0.68(0.30)$ & $0.08(0.04)$ \\
\hline
\end{tabular}

Trial 5

In Trial 5 cumulative doses ranging from 280 to $840 \mu \mathrm{g}$ of MC-LR were fed to the fish, resulting in estimated body burdens of 104,000-290,000 $\mu \mathrm{g} / \mathrm{kg}$ biomass assuming that all of the microcystin was incorporated into the body (table 4). In contrast to Trial 4 only 25 percent of the fish consumed their entire meal within 2 h, 50 percent within 3 h, 70 percent within 4 h, and 90 percent within $5 \mathrm{~h}$. There was no pattern of consumption associated with microcystin concentration including controls. All fish consumed their entire meals within $24 \mathrm{~h}$. Average water temperature was $15.4{ }^{\circ} \mathrm{C}$ compared to $18.1{ }^{\circ} \mathrm{C}$ in the previous chronic trial (table 1), which we assume caused the slower consumption time in Trial 5. There were no histopathological abnormalities associated with microcystin exposure. Microcystin antigen was detected by immunohistochemistry in the lower intestine epithelial cells and digestive contents of all five high dose fish examined (fig. 1) and in the upper intestine epithelium and digestive contents of 
60 percent of fish. A positive reaction was also present in all livers examined (table 5). Free MCLR was detected in all the exposed fish (table 7); however, there was no significant difference in percentage of free MC-LR recovered (Kruskal-Wallis $\chi^{2}=1.84, \mathrm{df}=1, \mathrm{p}=0.175$ ). Less than 1 percent of the microcystin was recovered in the free state.
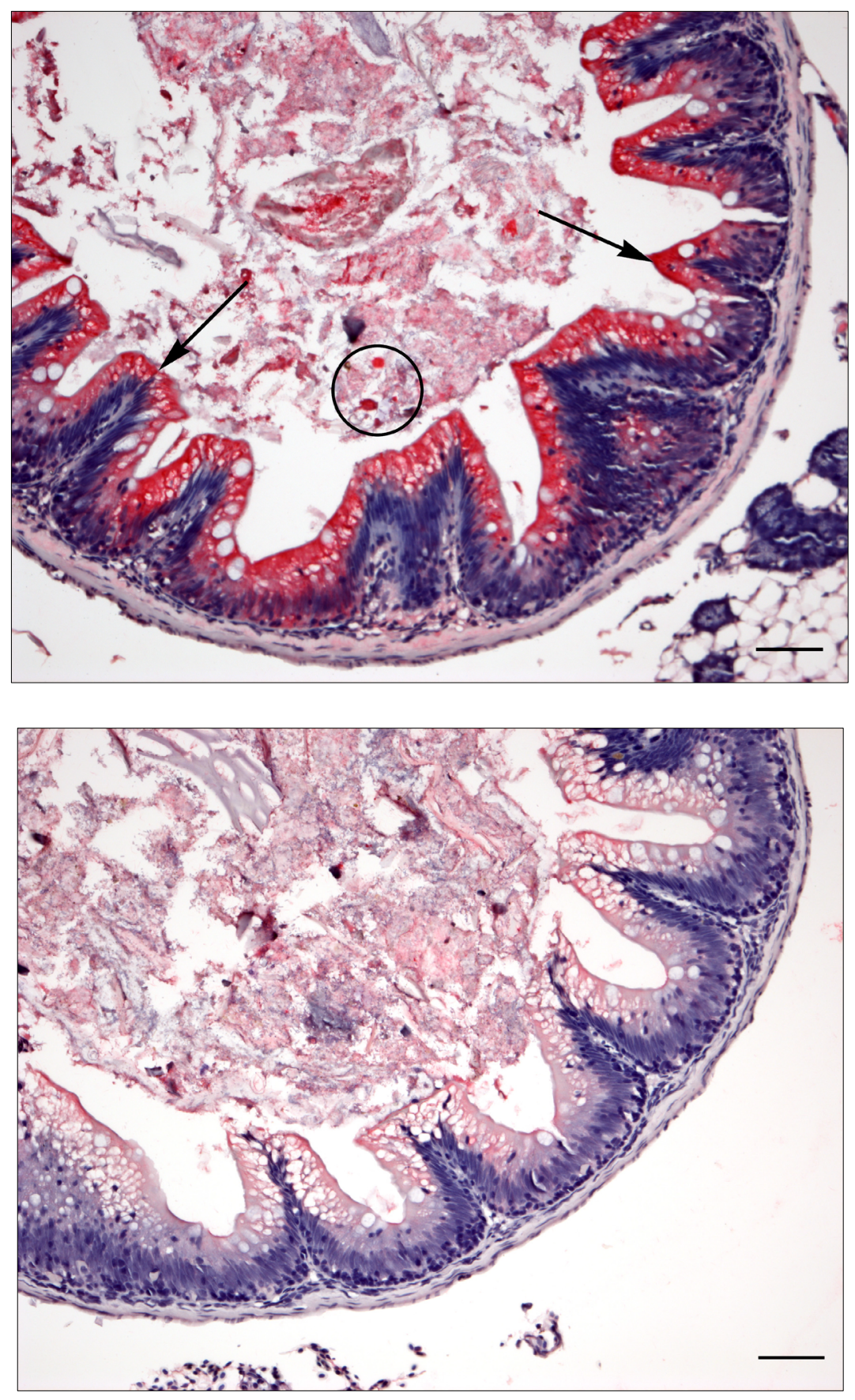

Figure 1. Images showing (upper) immunohistochemical staining (red) of posterior intestinal epithelial tissue (arrows) and digestive contents (circled) for microcystin-LR in a fish that received a daily 60 microgram dose for 14 days in Trial 5 and (lower) no staining in negative controls. Scale bar is 50 micrometers. Fish were euthanized for immunohistochemical analysis 24 hours after the last feeding. 


\section{Discussion}

Our feeding studies showed that Lost River suckers survived after ingestion of a single dose of $60 \mu \mathrm{g}$ pure MC-LR resulting in a cumulative body burden of $20,000 \mu \mathrm{g} / \mathrm{kg}$ bm with no histopathological abnormalities. Channel catfish (Ictalurus punctatus) survived the same body burden of pure MC-LR, but histopathological damage was observed $48 \mathrm{~h}$ post gavage with only minor histopathological damage 7 days post gavage (Snyder and others, 2002). Differences in histological responses between these two studies could be due to different tolerances between species, or to delivering the toxin in food rather than by gavage. There is always the possibility that the gavage process might damage the fish and create a direct to blood route of exposure.

It is possible that the full intended dose wasn't received though feeding in our study. Because we found that oral gavage was not a good method of toxin delivery for small juvenile Lost River suckers, toxicity differences between gavage and feeding trials could not be determined. We also did not find any literature that compared these two methods, but many studies use ingestion of microcystin contaminated foods to study effects on fish (Xie, and others, 2004; Li and others, 2005; Shen and others, 2005; Zhao and others 2006a and b; Acuna and others, 2012a and b; Deng and others, 2010; Dyble and others, 2011; Dong and others, 2012; Biecynski and others, 2013 and 2016; Qiao and others, 2013). We did however, take several steps to confirm that our study fish were receiving a full dose of toxin. We confirmed that less than 1 percent of the toxin leached from the food pellets within $24 \mathrm{~h}$. Not only did we observe fish eating the spiked food pellets, positive immunohistochemistry in gut contents, confirmed that the toxin was ingested. Although, less than 1 percent of microcystin was recovered in most trials, between 1-2 percent of the delivered toxin was recovered as free microcystin from whole body samples after a 24-h holding time in Trial 1 . This low recovery rate is consistent with the findings of Shen and others (2005), who fed silver carp (Hypophthalmichthys molitrix) MC-LR and recovered 90.7 percent of the delivered dose in the feces. Xie and others (2005) suggested that lower trophic level fish (which would include Lost River suckers) were more likely to eliminate microcystin than higher trophic level (piscivorous) fish. Xie and others (2004) suggest that MC-LR is actively degraded during digestion, while other forms such as MC-RR are more likely to be transported across the intestine and embedded into the tissues. Furthermore, He and others (2012) and Li and others (2014) documented the glutathione and cysteine pathways that allow excretion of microcystins in bighead carp (Aristichthys nobilis) IP-injected with purified MC-LR and MC-RR. Biecynski and others (2013 and 2016) found the same pathway was involved in excreting microcystin in the Patagonian silverside (Odontesthes hatcheri) fed crude microcystin laced food pellets. Although Lost River suckers do not feed directly on Microcystis cyanobacteria, we assume they would have a similar method of excretion of microcystin. Therefore, we hypothesize that the low recovery rate of free microcystin in the whole-body samples was mostly due to excretion of microcystin rather than an ineffective method of toxin delivery. Furthermore, if MC-LR is more likely to be actively degraded during digestion as Xie and others (2004) suggest then we would not expect much in the way of symptomology with regards to damage of the internal organs.

Crude cyanobacterial extracts are generally far more toxic than purified toxins (Pietsch and others, 2001; Ibelings and Chorus, 2007; Ibelings and Havens, 2008, Le Manach and others, 2016), which could explain why suckers in our study tolerated much greater body burdens than fish in studies that used crude extracts or fish fed whole cells of cyanobacteria. For example, median lethal doses of microcystin delivered by gavage as lysed whole cells of $M$. aeruginosa range from $1,700 \mu \mathrm{g} / \mathrm{kg} \mathrm{bm}$ within $72-96 \mathrm{~h}$ for common carp to $6,600 \mu \mathrm{g} / \mathrm{kg}$ bm for rainbow 
trout (Fischer and Dietrich, 2000). One reason crude extracts are more toxic is that they often contain more than one variant of microcystin, which can exhibit variation in toxicity levels (Shen and others, 2005; Xie and others, 2005; Zhao and others, 2006b; Ibelings and Havens, 2008; Issam and others, 2010; Qiao and others, 2013; Pick, 2016). Another possibility is that there is a synergistic effect between the microcystin and other metabolites such as lipopolysaccharides, other bacteria, or other dissolved organic materials (Pietsch and others, 2001; Li and others, 2005; Ibelings and Havens, 2008; Acuna and others, 2012a; Paskerova and others, 2012; Le Manach and others, 2016). It has been hypothesized that the cyanobacteria themselves, other bacteria, and lipopolysaccharides interfere with detoxification processes such as the glutathione pathway (Pietsch and others, 2001; Ibelings and Havens, 2008: Lemes and others, 2008; Paskerova and others, 2012).

We assumed that due to the food web route of exposure suckers were likely exposed to the pure form of the toxin. That is, we assumed that secondary metabolites of M. aeruginosa were processed through the food web and not associated with microcystin exposure to suckers. We found no information in the literature to support or refute this assumption, but if it were to be found incorrect the toxicity of microcystins to suckers may be greater than we determined in this study. We did not consider incidental or direct feeding on M. aeruginosa cells, which would expose suckers to a crude form of the toxin. Based on available diet studies, it seems unlikely that Lost River suckers are incidentally consuming high volumes of cyanobacteria (Markle and Clauson, 2006; VanderKooi and others, 2010).

We examined the toxicity of MC-LR, because it is known to be present in Upper Klamath Lake and the lethal effects have been examined for other fishes. The LR and LA are two of the most toxic variants of microcystin when injected into mice (Zurawell and others, 2005). In contrast, the other variant (YR) known to be in Upper Klamath Lake was about half as toxic to mice (Zurawell and others, 2005). The detoxification pathway has been documented for the LR and RR variants in fish (He and others, 2012; Li and others, 2014), but is unconfirmed for LA or YR. It may be possible that the LA and YR variants cannot be excreted as easily as the LR used in our study.

An interaction between warmer water temperatures and microcystin toxicity may explain the abnormal swimming behavior of fish in the highest dose exposure in Trial 2. Water temperatures in this trial were the most variable (table 1). Microcystin-LR toxicity to intraperitoneal injected zebrafish (Danio rerio) is greater at higher water temperatures as seen by increased cellular histopathological damage in the tissues (Ji and others, 2013) and decreased $\mathrm{LD}_{50}$ as temperature rises $\left(12^{\circ} \mathrm{C} \mathrm{LD}_{50} 547 \mu / \mathrm{kg} ; 2{ }^{\circ} \mathrm{C} \mathrm{LD} \mathrm{LD}_{50} 260 \mu / \mathrm{kg} ; 32{ }^{\circ} \mathrm{C} \mathrm{LD}_{50} 176 \mu / \mathrm{kg}\right.$; Zhang and others, 2011). Trial 2 did not have the greatest average water temperatures in our study but had the highest maximum water temperatures and the greatest variability in water temperatures. This variability may have contributed to overall stress that fish experienced in this trial. Water temperatures in our experiments were lower than maximum summer-time water temperatures in Upper Klamath Lake. Therefore, if there is an interaction between water temperature and microcystin exposure for Lost River suckers, our study may have underestimated toxicity.

Although MC-LR concentrations in Upper Klamath Lake are likely to be too low to kill Lost River suckers directly they may indirectly affect fish through several sub-lethal responses. Microcystin can cause oxidative stress, promote tumors in the liver, disrupt ion regulation, and reduce heart rate (Ibelings and Havens, 2008; Pavagadhi and Balasubramanian 2013). Whitefish (Coregonus lavaretus) exposed to higher rather than lower doses of microcystins were more 
susceptible to the parasite Ichthyophthirius (Ernst and others, 2007). Microcystins can reduce growth, muscle mass, RNA:DNA ratios, and glycogen storage (Zhao and others, 2006b; Acuna and other, 2012), although these growth effects are more pronounced on planktivores than on fish feeding primarily on benthic invertebrates (Acuna and others, 2012a; Acuna and others, 2012b). At low concentrations, microcystin (1-20 $\mu \mathrm{g} / \mathrm{L})$ absorbed through the gills accumulated in the gonads of zebrafish and the effects were passed to the F1 generation (Liu and others, 2014). The F1 zebrafish of exposed parents had lower hatching success, larvae were deformed, grew slower, and had liver damage characteristic of higher concentration microcystin exposures in adult fish. Microcystin can also affect behavior and reduce overall locomotion (Pavagadhi and Balasubramanian, 2013). In humans, microcystins caused visual disturbances, nausea, vomiting, and muscle weakness, symptoms that would be difficult to verify for fish (Pavagadhi and Balasubramanian, 2013).

Cyanotoxins can result in massive mortality of benthic invertebrates, such as those that suckers prey on (Krzyanek and others, 1993; Zurawell and others, 2005). Toporowska and others (2014) found that Chironomus spp. fed various variants of microcystin were smaller and many failed to complete their development, which might decrease the food supply of chironomids during or immediately after microcystin blooms. Microcystin-LR can be absorbed and metabolized by wetland plants, which may subsequently reduce the size and health of wetlands that suckers sometimes use (Pflugmacher and others, 2001). In conclusion, direct MC-LR toxicity is unlikely to be the primary cause for the mortality of young suckers in Upper Klamath Lake but it might indirectly affect sucker survival.

\section{Acknowledgments}

Scott Foott and Ron Stone of U.S. Fish and Wildlife California-Nevada Fish Health Center provided the juvenile suckers for this study. The Klamath Tribes provided their hatchery for the experimental trials. Debbie McCollam and Don McDonnell of the Medical Imaging Technology Department from Oregon Institute of Technology provided the equipment and expertise to check the path of gavaged liquid into the juvenile Lost River suckers. 


\section{References Cited}

Acuna, S., Baxa, D., and The, S., 2012a, Sublethal dietary effects of microcystin producing Microcystis on threadfin shad, Dorosoma petenense: Toxicon, v. 60, no. 6, p. 1191-1202, accessed January 27, 2017, at https://doi.org/10.1016/j.toxicon.2012.08.004.

Acuna, S., Deng, D., Lehman, P., and Teh, S., 2012b, Sublethal dietary effects of Microcystis on Sacramento splittail, Pogonichthys macrolepidotus: Aquatic Toxicology (Amsterdam, Netherlands), v. 110-111, p. 1-8, accessed December 31, 2013, at https://doi.org/10.1016/j.aquatox.2011.12.004.

Anderson, R.J., Hue, A.L., Chen, D.Z.H., Holmes, C.F.B., Kent, M.L., Le Blanc, M., Taylor, F.J.R., and Williams, D.E., 1993, Chemical and biological evidence links microcystin to 'salmon netpen disease': Toxicon, v. 31, no. 10, p. 1315-1320, accessed April 18, 2019, at https://doi.org/10.1016/0041-0101(93)90404-7.

Bieczynski, F., Bianchi, V.A., and Luquet, C.M., 2013, Accumulation and biochemical effects of microcystin-LR on the Patagonian pejerrey (Odontesthes hatcheri) fed with the toxic cyanobacteria Microcystis aeruginosa: Fish Physiology and Biochemistry, v. 39, no. 5, p. 1309-1321, accessed December 31, 2013, at https://doi.org/10.1007/s10695-013-9785-7.

Bieczynski, F., Torres, W.D.C., Painefilu, J.C., Castro, J.M., Bianchi, V.A., Frontera, J.L., Paz, D.A., Gonzalez, C., Martin, A., Villanueva, S.S.M., and Luquet, C.M., 2016, Alterations in the intestine of Patagonian silverside (Odontesthes hatcheri) exposed to microcystin-LR Changes in the glycosylation pattern of the intestinal wall and inhibition of multidrug resistance proteins efflux activity: Aquatic Toxicology (Amsterdam, Netherlands), v. 178, p. 106-117, accessed December 9, 2016, at https://doi.org/10.1016/j.aquatox.2016.07.016.

Burdick, S.M., Elliott, D.G., Ostberg, C.O., Conway, C.M., Dolan-Caret, A., Hoy, M.S., Feltz, K.P., and Echols, K.R., 2015, Health and condition of endangered juvenile Lost River and shortnose suckers relative to water quality and fish assemblages in Upper Klamath Lake, Oregon, and Clear Lake Reservoir, California: U.S. Geological Survey Open-File Report 2015-1217, 56 p., accessed February 13, 2019, at http://dx.doi.org/10.3133/ofr20151217.

Burdick, S.M., Conway, C.M., Elliott, D.G., Hoy, M.S., Dolan-Caret, A., and Ostberg, C.O., 2017, Health and condition of endangered young-of-the-year Lost River and shortnose suckers relative to water quality in Upper Klamath Lake, Oregon, 2014-2015: U.S. Geological Survey Open-File Report 2017-1134, 40 p., accessed February 13, 2019, at https://doi.org/10.3133/ofr20171134.

Burdick, S.M., and Martin, B.A., 2017, Inter-annual variability in apparent relative production, survival, and growth of juvenile Lost River and shortnose suckers in Upper Klamath Lake, Oregon, 2001-2015: U.S. Geological Survey Open-File Report 2017-1069, 55 p., accessed February 13, 2019, at https://doi.org/10.3133/ofr20171069.

Caldwell Eldridge, S.L., Wood, T.M., Echols, K.R., and Topping, B.R., 2013, Microcystins, nutrient dynamics, and other environmental factors during blooms of non-microcystinproducing Aphanizomenon flos-aquae in Upper Klamath Lake, Oregon, 2009: Lake and Reservoir Management, v. 29, no. 1, p. 68-81, accessed May 21, 2014, at https://doi.org/10.1080/10402381.2013.775199.

Cazenave, J., Wunderlin, D.A., Bistoni, M.A., Ame, M.V., Krause, E., Pflugmacher, S., and Wiegand, C., 2005, Uptake, tissue distribution and accumulation of microcystin-RR in 
Corydoras paleatus, Jenynsia multidentata and Odontesthes bonariensis A field and laboratory study: Aquatic Toxicology (Amsterdam, Netherlands), v. 75, no. 2, p. 178-190, accessed January 27, 2017, at https://doi.org/10.1016/j.aquatox.2005.08.002.

Deng, D.F., Zheng, K., The, F.C., Lehman, W.W., and The, S.J., 2010, Toxic threshold of dietary microcystin (-LR) for quart medaka: Toxicon, v. 55, no. 4, p. 787-794, accessed February 10, 2017, at https://doi.org/10.1016/j.toxicon.2009.11.012.

Dong, G., Xie, S., Zhu, X., Han, D., Yang, Y., Song, L., Gan, L., and Chen, W., 2012, Responses of yellow catfish (Pelteobagrus fulvidraco Richardson) exposed to dietary cyanobacteria and subsequent recovery: Toxicon, v. 60, no. 7, p. 1298-1306, accessed December 31, 2013, at https://doi.org/10.1016/j.toxicon.2012.08.013.

Driscoll, C.B., Meyer, K.A., Sulcius, S., Brown, N.M., Dick, G.J., Cao, H., Gasiunas, G., Timinskas, A., Yin, Y., Landry, Z.C., Otten, T.G., Davis, T.W., Watson, S.B., and Dreher, T.W., 2018, A closely-related clade of globally distributed bloom-forming cyanobacteria within the Nostoclaes: Harmful Algae, v. 77, p. 93-107, accessed February 13, 2019, at https://doi.org/10.1016/j.hal.2018.05.009.

Dyble, J., Gossiaux, D., Landrum, P., Kashian, D.R., and Pothoven, S., 2011, A kinetic study of accumulation and elimination of microcystin-LR in yellow perch (Perca flavescens) tissue and implications for human fish consumption: Marine Drugs, v. 9, no. 12, p. 2553-2571, accessed February 13, 2017, at https://doi.org/10.3390/md9122553.

Echols, K.R., and Jones, S.B., 2005, Cyanobacterial toxins: a comparison of method measurements in field collected samples. Verhandlungen Internationale Vereinigung für theoretische und angewandte Limnologie. Proceedings of the 29th Congress: (Presented at SIL, Lahti, Finland, 8-14 August 2004): 2005, 29:212-216, accessed February 13, 2019, at https://doi.org/10.1080/03680770.2005.11901998.

Eldridge, S.L.C., Wood, T.M., and Echols, K.R., 2012, Spatial and temporal dynamics of cyanotoxins and their relation to other water quality variables in Upper Klamath Lake, Oregon, 2007-09: U.S. Geological Survey Scientific Investigations Report 2012-5069, 34 p, accessed May 21, 2014, at https://doi.org/10.3133/sir20125069.

Ernst, B., Hoeger, S.J., O’Brien, E., and Dietrich, D.R., 2007, Physiological stress and pathology in European whitefish (Coregonus lavaretus) induced by subchronic exposure to environmentally relevant densities of Planktothrix rubescens: Aquatic Toxicology (Amsterdam, Netherlands), v. 82, no. 1, p. 15-26, accessed February 14, 2017, at https://doi.org/10.1016/j.aquatox.2007.01.007.

Fischer, W.J., and Dietrich, D.R., 2000, Pathological and biochemical characterization of microcystin-induced hepatopancreas and kidney damage in carp (Cyprinus carpio):

Toxicology and Applied Pharmacology, v. 164, no. 1, p. 73-81, accessed November 20, 2015, at https://doi.org/10.1006/taap.1999.8861.

Foott, J.S., Stone, R., Wilkens, A., and Rasmussen, J., 2012, Juvenile Lost River Sucker survival and energetics in Upper Klamath Lake mesocosm cages (July-December 2011)-Report of the California Nevada Fish Health Center: U.S. Fish and Wildlife Service Office Anderson, 49 p.

Foott, J.S., Stone, R., and Wilkens, A., 2014, Juvenile Lost River Sucker Sentinel Survival in Upper Klamath Lake Mesocosm Cages (July-October 2013) and laboratory hypoxic challenge-Report of the California Nevada Fish Health Center: U.S. Fish and Wildlife Service Office Anderson, $65 \mathrm{p}$.

Guo, X., Xie, P., Chen, J., Tuo, X., Deng, X., Li, S., Yu, D., and Zeng, X., 2014, Simultaneous quantitative determination of microcystin-LR and its glutathione metabolites in rat liver by 
liquid chromatography-tandem mass spectrometry: Journal of Chromatography. B, Analytical Technologies in the Biomedical and Life Sciences, v. 963, p. 54-61, accessed February 13, 2019, at https://doi.org/10.1016/j.jchromb.2014.05.046.

He, J., Chen, J., Xie, P., Zhang, D., Li, G., Wu, L., Zhang, W., Guo, X., and Li, S., 2012, Quantitatively evaluating detoxification of the hepatotoxic microcystins through the glutathione and cysteine pathway in the cyanobacteria-eating bighead carp: Aquatic Toxicology (Amsterdam, Netherlands), v. 116-117, p. 61-68, accessed December 19, 2016, at https://doi.org/10.1016/j.aquatox.2012.03.004.

Hewitt, D.A., Janney, E.C., Hayes, B.S., and Harris, A.C., 2015, Status and trends of adult Lost River (Deltistes luxatus) and shortnose (Chasmistes brevirostris) sucker populations in Upper Klamath Lake, Oregon, 2014: U.S. Geological Survey Open-File Report 2015-1189, 36 p., accessed February 13, 2019, at http://dx.doi.org/10.3133/ofr20151189.

Ibelings, B.W., and Chorus, I., 2007, Accumulation of cyanobacterial toxins in freshwater "seafood" and its consequences for public health-A review: Environmental Pollution, v. 150, no. 1, p. 177-192, accessed March 13, 2014, at https://doi.org/10.1016/j.envpol.2007.04.012.

Ibelings, B.W., and Havens, K.E., 2008, Cyanobacterial toxins-A qualitative meta-analysis of concentrations, dosage and effects in freshwater, estuarine and marine biota, in Hudnell, H.K., ed., Cyanobacterial Harmful Algal Blooms-State of the Science and Research Needs v. 619: Berlin, Germany, Springer-Verlag Berlin, p. 675-732, accessed February 2, 2017, at https://doi.org/10.1007/978-0-387-75865-7_32.

Issam, E.G., Sanaa, S., Paulo, C.A., Youness, O., Francisca, D.C.F., Brahim, O., and Vitor, V., 2010, Effect of different microcystin profiles on toxin bioaccumulation in common carp (Cyprinus carpio) larvae via Artemia nauplii: Ecotoxicology and Environmental Safety, v. 73, no. 5, p. 762-770, accessed March 31, 2015, at https://doi.org/10.1016/j.ecoenv.2009.12.015.

Jacoby, J.M., and Kann, J., 2007, The occurrence and response to toxic cyanobacteria in the Pacific Northwest, North America: Lake and Reservoir Management, v. 23, no. 2, p. 123-143, accessed February 23, 2017, at https://doi.org/10.1080/07438140709353916.

Janik, A.J., Markle, D.F., Heidel, J.R., and Kent, M.L., 2018, Histopathology and external examination of heavily parasitized Lost River Sucker Deltistes luxatus (Cope 1879) and Shortnose Sucker Chasmistes brevirostris (Cope 1879) from Upper Klamath Lake, Oregon: Journal of Fish Diseases, v. 41, no. 11, p. 1675-1687, accessed April 17, 2019, at https://doi.org/10.1111/jfd.12875.

Ji, W., Liang, H., Zhou, W., and Zhang, X., 2013, Apoptotic responses of zebrafish (Danio rerio) after exposure with microcystin-LR under different ambient temperatures: Journal of Applied Toxicology, v. 33, no. 8, p. 799-806, accessed January 7, 2014, at https://doi.org/10.1002/jat.2735.

Kotak, B.G., Zurawell, R.W., Prepas, E.E., and Holmes, C.F.B., 1996, Microcystin-LR concentration in aquatic food web compartments from lakes of varying trophic status: Canadian Journal of Fisheries and Aquatic Sciences, v. 53, no. 9, p. 1974-1985, accessed January 23, 2012, at https://doi.org/10.1139/cjfas-53-9-1974.

Kozlowsky-Suzuki, B., Wilson, A.E., and Ferrao-Filho, A.D.S., 2012, Biomagnification or biodilution of microcystins in the aquatic foodwebs? Meta-analyses of laboratory and field studies: Harmful Algae, v. 18, p. 47-55, accessed January 26, 2017, at https://doi.org/10.1016/j.hal.2012.04.002. 
Krzyzanek, E., Kasza, H., and Grazyna, P., 1993, The effect of water blooms caused by bluegreen algae on the bottom macrofaunal in the Goczalkowice Reservoir (southern Poland) in 1992: Acta Hydrobiologica (Cracow), v. 35, p. 221-230.

Le Manach, S., Khenfech, N., Huet, H., Qiao, Q., Duval, C., Marie, A., Bolbach, G., Clodic, G., Djediat, C., Bernard, C., Edery, M., and Marie, B., 2016, Gender-specific toxicological effects of chronic exposure to pure microcystin-LR or complex Microcystis aeruginosa extracts on adult medaka fish: Environmental Science \& Technology, v. 50, no. 15, p. 8324-8334, accessed December 9, 2016, at https://doi.org/10.1021/acs.est.6b01903.

Lemes, G.A.F., Kersanach, R., Pinto, L.D.S., Dellagostin, O.A., Yunes, J.S., and Matthiensen, A., 2008, Biodegradation of microcystin by aquatic Burkholderia sp. From a South Brazilian coastal lagoon: Ecotoxicology and Environmental Safety, v. 69, p. 358-365, accessed January 25, 2017, at https://doi.org/10.1016/j.ecoenv.2007.03.013.

Li, X.Y., Chung, I.K., Kim, J.I., and Lee, J.A., 2005, Oral exposure to Microcystis increases activity-augmented antioxidant enzymes in the liver of loach (Misgurnus mizolepis) and has no effect on lipid peroxidation: Comparative Biochemistry and Physiology, v. 141, no. Part C, p. 292-296.

Li, W., Chen, J., Xie, P., He, J., Guo, X., Tuo, X., Zhang, W., and Wu, L., 2014, Rapid conversion and reversible conjugation of glutathione detoxification of microcystins in bighead carp (Aristichthys nobilis): Aquatic Toxicology (Amsterdam, Netherlands), v. 147, p. 18-25, accessed January 6, 2017, at https://doi.org/10.1016/j.aquatox.2013.12.001.

Liu, W., Qiao, Q., Chen, Y., Wu, K., and Zhang, X., 2014, Microcystin-LR exposure to adult zebrafish (Danio rerio) leads to growth inhibition and immune dysfunction in F1 offspring, a parental transmission effect of toxicity: Aquatic Toxicology (Amsterdam, Netherlands), v. 155, p. 360-367, accessed March 31, 2015, at https://doi.org/10.1016/j.aquatox.2014.07.011.

Malbrouck, C., and Kestemont, P., 2006, Effects of microcystins on fish: Environmental Toxicology and Chemistry, v. 25, no. 1, p. 72-86, accessed May 22, 2019, at https://doi.org/10.1897/05-029R.1.

Malbrouck, C., Trausch, G., Devos, P., and Kestemont, P., 2003, Hepatic accumulation and effects of microcystin-LR on juvenile goldfish Carassius auratus L: Comparative Biochemistry and Physiology, v. 135, no. Part C, p. 39-48.

Malbrouck, C., Trausch, G., Devos, P., and Kestemont, P., 2004, Effects of microcystin-LR on protein phosphatase activity and glycogen content in isolated hepatocytes of fed and fasted juvenile goldfish Carassius auratus L: Toxicon, v. 44, no. 8, p. 927-932, accessed May 22, 2019, at https://doi.org/10.1016/j.toxicon.2004.09.003.

Markle, D.F., and Clauson, K., 2006, Ontogenetic and habitat-related changes in diet of late larval and juvenile suckers (Catostomidae) in Upper Klamath Lake, Oregon: Western North American Naturalist, v. 66, no. 4, p. 492-501, accessed February 13, 2019, at https://doi.org/10.3398/1527-0904(2006)66[492:OAHCID]2.0.CO;2.

Martin, B.A., 2018, Methods used for rearing Lost River suckers (Deltistes luxatus): U.S. Geological Survey Administrative Report, 14 p.

Paskerova, H., Hilscherova, K., and Blaha, L., 2012, Oxidative stress and detoxification biomarker responses in aquatic freshwater vertebrates exposed to microcystins and cyanobacterial biomass: Environmental Sciences Pollution Reseach, v. 19, no. 6, p. 2024 2037, accessed January 26, 2017, at https://doi.org/10.1007/s11356-012-0960-7.

Pavagadhi, S., and Balasubramanian, R., 2013, Toxicological evaluation of microcystins in aquatic fish species - Current knowledge and future directions: Aquatic Toxicology 
(Amsterdam, Netherlands), v. 142-143, p. 1-16, accessed November 20, 2015, at https://doi.org/10.1016/j.aquatox.2013.07.010.

Pick, F.R., 2016, Blooming algae-A Canadian perspective on the rise of toxic cyanobacteria: Canadian Journal of Fisheries and Aquatic Sciences, v. 73, no. 7, p. 1149-1158, accessed December 8, 2016, at https://doi.org/10.1139/cjfas-2015-0470.

Pietsch, C., Wiegand, C., Ame, M.V., Nicklisch, A., Wunderlin, D., and Pflugmacher, S., 2001, The effects of a cyanobacterial crude extract on different aquatic organisms-Evidence for cyanobacterial toxin modulating factors: Environmental Toxicology, v. 16, no. 6, p. 535-542, accessed January 26, 2017, at https://doi.org/10.1002/tox.10014.

Pflugmacher, S., Wiegand, C., Beattie, K.A., Krause, E., Steinberg, C.E.W., and Codd, G.A., 2001, Uptake, effects, and metabolism of cyanobacterial toxins in the emergent reed plant Phragmites australis (Cav.) Trin. Ex Steud: Environmental Toxicology and Chemistry, v. 20, no. 4, p. 846-852, accessed January 30, 2017, at https://doi.org/10.1002/etc.5620200421.

Qiao, Q., Liu, W., Wu, K., Song, T., Hu, J., Huang, X., Wen, J., Chen, L., and Zhang, X., 2013, Female zebrafish (Danio rerio) are more vulnerable than males to microcystin-LR exposure, without exhibiting estrogenic effects: Aquatic Toxicology (Amsterdam, Netherlands), v. 142143, p. 272-282, accessed December 30, 2013, at https://doi.org/10.1016/j.aquatox.2013.07.002.

Roy-Lachepelle, A., Solliec, M., Bouchard, M.F., and Sauve, S., 2017, Detection of cyantoxins in algae dietary supplements: Toxins, v. 9, p. 1-17.

Shen, Q., Hu, J., Li, D., Wang, G., and Liu, Y., 2005, Investigation on intake, accumulation and toxicity of microcystins to silver carp: Fresenius Environmental Bulletin, v. 14, p. 1124-1128.

Snyder, G.S., Goodwin, A.E., and Freeman, D.W., 2002, Evidence that channel catfish, Ictalurus punctatus (Rafinesque), mortality is not linked to ingestion of the hepatoxin microcystin-LR: Journal of Fish Diseases, v. 25, no. 5, p. 275-285, accessed February 6, 2014, at https://doi.org/10.1046/j.1365-2761.2002.00374.x.

Tencalla, F., and Dietrich, D., 1997, Biochemical characterization of microcystin toxicity in rainbow trout (Oncorhynchus mykiss): Toxicon, v. 35, no. 4, p. 583-595, accessed December 30, 2013, at https://doi.org/10.1016/S0041-0101(96)00153-5.

Toporowska, M., Pawlik-Skowronska, B., and Kalinowska, R., 2014, Accumulation and effects of cyanobacterial microcystins and anatoxin-a on benthic larvae of Chironomus spp.

(Diptera-Chironomidae): European Journal of Entomology, v. 111, no. 1, p. 83-90, accessed January 20, 2017, at https://doi.org/10.14411/eje.2014.010.

U.S. Fish and Wildlife Service (USFWS), 1988, Endangered and threatened wildlife and plants; determination of endangered status for the shortnose sucker and Lost River sucker: Federal Register, v. 53, p. 27130-27134.

U.S. Fish and Wildlife Service (USFWS), 2012, Revised recovery plan for the Lost River sucker (Deltistes luxatus) and shortnose sucker (Chasmistes brevirostris): U.S. Fish and Wildlife Service, Pacific Southwest Region, Sacramento, California. xviii $+122 \mathrm{pp}$.

VanderKooi, S.P., Burdick, S.M., Echols, K.R., Ottinger, C.A., Rosen, B.H., and Wood, T.M., 2010, Algal toxins in upper Klamath Lake, Oregon-Linking water quality to juvenile sucker health: U.S. Geological Survey Fact Sheet 2009-3111, 2 p, accessed February 13, 2019, at https://doi.org/10.3133/fs20093111

Xie, L., Xie, P., Guo, L., Li, L., Miyabara, Y., and Park, H., 2005, Organ distribution and bioaccumulation of microcystins in freshwater fish at different trophic levels from the 
eutrophic Lake Chaohu, China: Environmental Toxicology, v. 20, no. 3, p. 293-300, accessed January 30, 2017, at https://doi.org/10.1002/tox.20120.

Xie, L., Xie, P., Ozawa, K., Honma, T., Yokoyama, A., and Park, H., 2004, Dynamics of microcystins-LR and -RR in the phytoplanktivorous silver carp in a sub-chronic toxicity experiment: Environmental Pollution, v. 127, no. 3, p. 431-439, accessed January 26, 2012, at https://doi.org/10.1016/j.envpol.2003.08.011.

Zhang, X., Wei, J., Zhang, H., Zhang, W., and Xie, P., 2011, Studies on the toxic effects of microcystin-LR on the zebrafish (Danio rerio) under different temperatures: Journal of Applied Toxicology, v. 31, no. 6, p. 561-567, accessed January 20, 2012, at https://doi.org/10.1002/jat.1597.

Zhao, M., Xie, S., Zhu, M., Yang, Y., Gan, N., and Song, L., 2006a, Effect of dietary cyanobacteria on growth and accumulation of microcystins in Nile tilapia (Oreochromis niloticus): Aquaculture (Amsterdam, Netherlands), v. 261, no. 3, p. 960-966, accessed February 4, 2014, at https://doi.org/10.1016/j.aquaculture.2006.08.019.

Zhao, M., Xie, S., Zhu, M., Yang, Y., Gan, N., and Song, L., 2006b, Effect of inclusion of bluegreen algae meal on growth and accumulation of microcystins in gibel carp (Carassius auratus gibelio): Journal of Applied Ichthyology, v. 22, no. 1, p. 72-78, accessed February 4, 2014, at https://doi.org/10.1111/j.1439-0426.2006.00706.x.

Zurawell, R.W., Chen, H., Burke, J.M., and Prepas, E.E., 2005, Hepatotoxic cyanobacteria-A review of the biological importance of microcystins in freshwater environments: Journal of Toxicology and Environmental Health, Part B, v. 8, p. 1-37. 
Publishing support provided by the U.S. Geological Survey Science Publishing Network, Tacoma Publishing Service Center

For more information concerning the research in this report, contact the Director, Western Fisheries Research Center

U.S. Geological Survey 6505 NE 65th Street

Seattle, Washington 98115-5016

https://www.usgs.gov/centers/wfrc 


\section{$\frac{\mathbb{2}}{3}$}

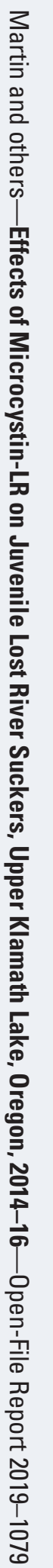

